\title{
Effects of nucleotide substitution and modification on the stability and structure of helix 69 from $28 \mathrm{~S}$ rRNA
}

\author{
MINAKO SUMITA, JEAN-PAUL DESAULNIERS, YU-CHENG CHANG, HELEN M.-P. CHUI, \\ LAWRENCE CLOS II, and CHRISTINE S. CHOW \\ Department of Chemistry, Wayne State University, Detroit, Michigan 48202, USA
}

\begin{abstract}
The helix 69 (H69) region of the large subunit (28S) rRNA of Homo sapiens contains five pseudouridine ( $\Psi$ ) residues out of 19 total nucleotides $(\mathbf{2 6} \%)$, three of which are universally or highly conserved. In this study, the effects of this abundant modified nucleotide on the structure and stability of $\mathrm{H69}$ were compared with those of uridine. The role of a loop nucleotide substitution from A in bacteria (position 1918 in Escherichia coli 23S rRNA) to $G$ in eukaryotes (position in 3734 in $H$. sapiens) was also examined. The thermodynamic parameters were obtained through UV melting studies, and differences in the modified and unmodified RNA structures were examined by ${ }^{1} \mathrm{H}$ NMR and circular dichroism spectroscopy. In addition, a $\left[1,3-{ }^{15} \mathrm{~N}\right] \Psi$ phosphoramidite was used to generate $\mathrm{H69}$ analogs with site-specific ${ }^{15} \mathrm{~N}$ labels. By using this approach, different $\Psi$ residues can be clearly distinguished from one another in ${ }^{1} \mathrm{H}$ NMR experiments. The effects of pseudouridine on $H$. sapiens $\mathrm{H} 69$ are consistent with previous studies on tRNA, rRNA, and snRNA models in which the nucleotide offers stabilization of duplex regions through $\Psi \mathrm{N} 1 \mathrm{H}$-mediated hydrogen bonds. The overall secondary structure and base-pairing patterns of human $\mathrm{H} 69$ are similar to the bacterial RNA, consistent with the idea that ribosome structure and function are highly conserved. Nonetheless, pseudouridine-containing RNAs have subtle differences in their structures and stabilities compared to the corresponding uridine-containing analogs, suggesting possible roles for $\Psi$ such as maintaining translation fidelity.
\end{abstract}

Keywords: helix 69; 28S rRNA; pseudouridine; modified nucleotides

\section{INTRODUCTION}

One of the most important biological functions of RNA is protein synthesis, which is carried out by the ribosome machinery throughout phylogeny. The three-dimensional (3D) structures of the complete $70 \mathrm{~S}$ ribosome and of its individual subunits have been solved at high resolution by X-ray crystallography (Cate et al. 1999; Ban et al. 2000; Carter et al. 2000; Nissen et al. 2000; Wimberly et al. 2000; Schlünzen et al. 2001; Yusupov et al. 2001). The 70S and $80 \mathrm{~S}$ ribosome complexes have also been observed by $3 \mathrm{D}$ cryo-electron microscopy (EM) (Frank and Agrawal 2000; Gabashvili et al. 2000; Spahn et al. 2001; Gao et al. 2003). The details of the 70S structure demonstrate that the RNA components of the complex must play critical roles in catalyzing peptide bond formation because there are no proteins in the vicinity of the A- and P-site tRNAs (Yusu-

Reprint requests to: Christine S. Chow, Department of Chemistry, Wayne State University, Detroit, MI 48202, USA; e-mail: csc@chem.wayne.edu; fax (313) 577-8822.

Article and publication are at http://www.rnajournal.org/cgi/doi/ $10.1261 /$ rna.2320605. pov et al. 2001). The $70 \mathrm{~S}$ crystal structure also revealed that helix 69 (H69) of 23S rRNA is a component of the major intersubunit bridge between the small and large subunits. This bridge, referred to as $\mathrm{B} 2 \mathrm{a}$, connects the peptidyl-transferase center (PTC) to the decoding region. The association of the ribosomal subunits is essential for protein synthesis; therefore, the bridges must have important roles in linking structure to function.

Helix 69 is observed in the $5.5 \AA$ resolution structure of the 70S complex (Yusupov et al. 2001) but disordered in the $2.4 \AA$ resolution structure of the $H$. marismortui 50 S subunit (Ban et al. 2000), suggesting that it has a dynamic role in structural rearrangements between the free and bound forms of the large subunit (Harms et al. 2001). It has been suggested that movement of H69 may contribute to tRNA placement and translocation (Bashan et al. 2003). Earlier cross-linking studies demonstrated that H69 of the Escherichia coli $23 \mathrm{~S}$ rRNA contacts the decoding region at positions 1408-1411 and 1518-1520 of 16S rRNA (Mitchell et al. 1992). Related chemical probing studies showed that helix 69 of 23S RNA also interacts with the 790 loop of $16 \mathrm{~S}$ rRNA, which is known to participate in subunit association, initiation factor binding, and tRNA binding (Joseph et al. 


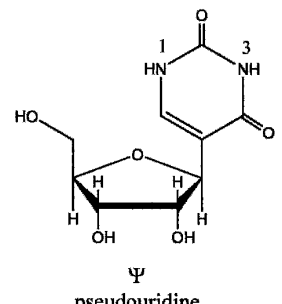

pseudouridine
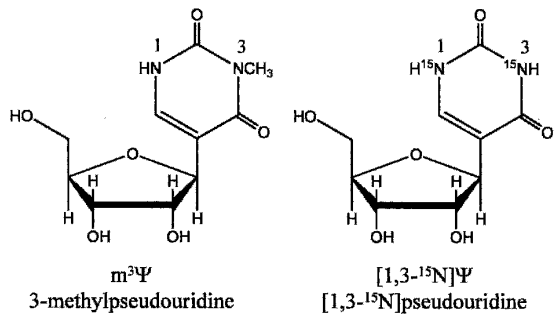

FIGURE 1. The structures of pseudouridine $(\Psi)$, 3-methylpseudouridine $\left(\mathrm{m}^{3} \Psi\right)$, and $\left[1,3-{ }^{15} \mathrm{~N}\right]$ pseudouridine $\left(\left[1,3-{ }^{15} \mathrm{~N}\right] \Psi\right)$.

1997; Merryman et al. 1999). More recently, DMS modification studies have shown that methylations at $A_{1912}$ and $\mathrm{A}_{1918}$ interfere with 70S ribosome function in E. coli (Maiväli and Remme 2004).

There are many known natural nucleoside modifications in RNA (Limbach et al. 1994; McCloskey and Crain 1998). The first to be discovered and one of the most common modified bases is pseudouridine (Cohn 1960; Ofengand et al. 1995; Charette and Gray 2000). Pseudouridine has its glycosidic bond between the base and sugar isomerized from a standard $\mathrm{Cl}^{\prime}-\mathrm{N} 1$ found in uridine to a $\mathrm{Cl}^{\prime}$-C5 bonding scheme (Fig. 1). Due to the isomerization reaction, pseudouridine has a second imino nitrogen available for hydrogen bonding. Interestingly, higher organisms have more pseudouridine residues in their large subunit rRNAs. Eukaryotic large subunit rRNAs contain $0.9 \%-1.4 \%$ pseudouridines compared to $0.03 \%-0.4 \%$ in bacteria, and the pseudouridine residues tend to be clustered in domains II, $\mathrm{IV}$, and $\mathrm{V}$ of the large subunit rRNAs (Maden and Wakeman 1988; Charette and Gray 2000). In H. sapiens, $7.3 \%$ of uridines in the large subunit rRNA are converted to pseudouridines compared to $1.5 \%$ in E. coli

(Ofengand and Bakin 1997).

In $\mathrm{H} 69$ of human rRNA, which is located in domain IV of $28 \mathrm{~S}$ rRNA, there are five pseudouridines out of 19 nucleotides and no uridine residues. Thus, the percentage of pseudouridines in $\mathrm{H} 69$ (26.3\%) is surprisingly high relative to the percentage in the remaining eukaryotic large subunit rRNA. Conserved pseudouridines $(\Psi)$ at positions 3727,3731 , and 3733 of $H$. sapiens $28 \mathrm{~S}$ rRNA correspond to $\Psi_{1911}, \Psi_{1915}$, and $\Psi_{1917}$ in E. coli $23 \mathrm{~S}$ rRNA, of which $\Psi_{1915}$ is also methylated at the N3 position (Figs. 1, 2) (Kowalak et al. 1996; Ofengand and Bakin 1997). There are two additional pseudouridines in the stem region of the $H$. sapiens RNA at positions 3737 and 3739.

Pseudouridine synthase RluD modifies uridines at positions 1911, 1915, and 1917 in E. coli 23 S rRNA (Wrze- sinski et al. 2000). In contrast, uridines at 3731 and 3733 in the human rRNA are guided to modification by the box $\mathrm{H} /$ ACA snoRNA known as U19 (Bortolin and Kiss 1998). The absence of RluD is reported to alter the growth rates of E. coli, and to influence stop codon readthrough and frameshifting of tRNA (O'Connor and Dahlberg 1995; Raychaudhuri et al. 1998). Similarly, snR191, the snoRNA for the corresponding U19 in S. cerevisiae, provides a growth rate advantage to the cell (Badis et al. 2003).

The sequence of $\mathrm{H} 69$ of the large subunit rRNA is highly conserved among organisms (Cannone et al. 2002). Most of the stem consists of $>88 \%$ conserved Watson-Click base pairs, with the exception of one G.U mismatch (Fig. 2; Table 1). The residue on the $3^{\prime}$ side of the seven-nucleotide loop is different between E. coli and H. sapiens. Most (>98\%) bacteria, including E. coli, have an A residue at position 1918 (E. coli numbering). In contrast, $>98 \%$ of eukaryotes, including $H$. sapiens, have a $G$ residue at the corresponding 3734 position. Highly conserved loop nucleotides $(98+\%)$ at positions 1913, 1914, and 1918 (E. coli numbering) are known to contact the minor groove of the small subunit rRNA decoding site (at residues 14081410 and 1494-1495) (Yusupov et al. 2001). The first and seventh positions of the H69 loop are possible determinants for stable loop-loop interactions (Gregorian and Crothers 1995). Thus, the base difference at position 1918/3734 (A versus G) could influence ribosome stability and function between eukaryotes and prokaryotes.

Helix 69 appears to play a significant role in ribosome function; therefore, it is important to determine the structural consequences of adding modified nucleotides $(\Psi)$ or altering its loop sequence. Since the ribosome structure has not been solved by X-ray crystallography in the unmodified
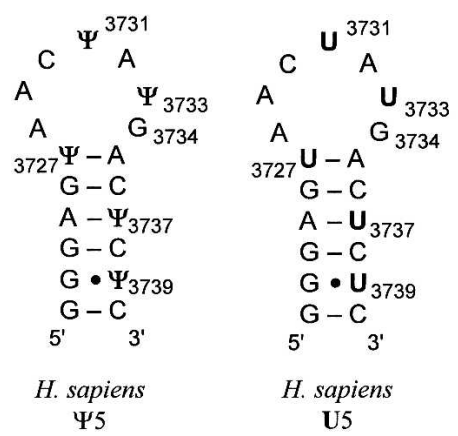

$\mathrm{ACGU}=98+\%$ conserved $;$ acgu $=88-90 \%$ conserved

FIGURE 2. The helix 69 (H69) RNA hairpins from H. sapiens and E. coli. The $\Psi 5$ and U5 RNAs are derived from positions $3722-3740$ of the H. sapiens large subunit rRNA. The natural sequence $(\Psi 5)$ contains pseudouridine $(\Psi)$ at positions $3727,3731,3733,3737$, and 3739 , whereas the unmodified variant (U5) contains uridine (U). The corresponding $\Psi \Psi \Psi$ and UUU RNAs are derived from positions $1906-1924$ of the E. coli $23 S$ rRNA. The UUU $\left(A_{1918} G\right)$ RNA contains a stem sequence corresponding to E. coli $\mathrm{H} 69$ and a loop of H. sapiens H69. The levels of $\mathrm{H} 69$ sequence conservation for bacteria and eukaryotes are indicated (ACGU indicates $98+\%$ conservation, and acgu indicates $88 \%-90 \%$ conservation). A total of 431 and 115 species were compared for bacteria and eukaryotes, respectively (Cannone et al. 2002). 
TABLE 1. Helix 69 sequence conservation

\begin{tabular}{|c|c|c|c|}
\hline E. coli & $\begin{array}{l}\% \text { Conservation } \\
\text { in bacteria }\end{array}$ & H. sapiens & $\begin{array}{c}\% \text { Conservation } \\
\text { in eukaryotes }\end{array}$ \\
\hline $\mathrm{G}_{1906}$ & $98+$ & $\mathrm{G}_{3722}$ & $98+$ \\
\hline $\mathrm{G}_{1907}$ & $98+$ & $\mathrm{G}_{3723}$ & $98+$ \\
\hline$C_{1908}$ & $88-90$ & $\mathrm{G}_{3724}$ & $98+$ \\
\hline$C_{1909}$ & $88-90$ & $A_{3725}$ & $98+$ \\
\hline $\mathrm{G}_{1910}$ & $98+$ & $\mathrm{G}_{3726}$ & $98+$ \\
\hline $\mathrm{U} / \Psi_{1911}$ & $98+$ & $\mathrm{U} / \Psi_{3727}$ & $98+$ \\
\hline$A_{1912}$ & $98+$ & $\mathrm{A}_{3728}$ & $98+$ \\
\hline$A_{1913}$ & $98+$ & $A_{3729}$ & $98+$ \\
\hline$C_{1914}$ & $98+$ & $\mathrm{C}_{3730}$ & $98+$ \\
\hline $\mathrm{U} / \Psi_{1915}$ & $98+$ & $\mathrm{U} / \Psi_{3731}$ & $98+$ \\
\hline $\mathrm{A}_{1916}$ & $98+$ & $A_{3732}$ & $98+$ \\
\hline$U / \Psi_{1917}$ & $98+$ & $\mathrm{U} / \Psi_{3733}$ & $98+$ \\
\hline $\mathrm{A}_{1918}$ & $98+$ & $\mathrm{G}_{3734}$ & $98+$ \\
\hline$A_{1919}$ & $98+$ & $A_{3735}$ & $98+$ \\
\hline$C_{1920}$ & $98+$ & $\mathrm{C}_{3736}$ & $98+$ \\
\hline $\mathrm{G}_{1921}$ & $88-90$ & $\mathrm{U} / \Psi_{3737}$ & $98+$ \\
\hline$G_{1922}$ & $88-90$ & $\mathrm{C}_{3738}$ & $98+$ \\
\hline$U_{1923}$ & $98+$ & $\mathrm{U} / \Psi_{3739}$ & $98+$ \\
\hline$C_{1924}$ & $98+$ & $\mathrm{C}_{3740}$ & $98+$ \\
\hline
\end{tabular}

Note: 431 species of bacteria and 115 species of eukaryotes were examined using the comparative RNA Web (CRW) site (http:// www.rna.icmb.utexas.edu) (Cannone et al. 2002).

form, the use of smaller model RNAs allows the comparison between modified and unmodified RNAs, and the comparison of RNAs from different organisms. In the present study, five H69 analogs (Fig. 2) based on the E. coli and $H$. sapiens large subunit rRNAs were examined for stability and structural differences. The U5 and UUU RNAs are the unmodified variants from human and bacteria, respectively, and contain uridines in place of pseudouridines. The $\Psi 5$ and $\Psi \Psi \Psi$ RNAs are the corresponding pseudouridinemodified analogs. The UUU $\left(\mathrm{A}_{1918} \mathrm{G}\right)$ RNA represents the bacterial sequence in which the loop residue at position 1918 is mutated from A to G. We employed circular dichroism (CD) spectroscopy, thermal melting experiments, and nuclear magnetic resonance (NMR) spectroscopy to analyze this set of RNAs, and we examined the effects of divalent metal ion $\left(\mathrm{Mg}^{2+}\right)$ binding to each of the RNAs.

\section{RESULTS}

\section{The effects of modification on the structure of H69 RNA analogs}

CD spectroscopy allows for indirect monitoring of conformational differences between RNAs or changes in RNA structure upon ligand binding. For example, the contributions of modified bases to RNA folding can be determined, and the conformational changes induced by metal ions can be assessed. The CD spectra of H69 RNAs were obtained in order to determine the effects of pseudouridine modification on the $H$. sapiens hairpin structures, and also to compare the human analogs with the previously studied E. coli RNAs (Meroueh et al. 2000; Chui et al. 2002). The spectra are shown as wavelength versus molar ellipticity $(\Delta \varepsilon)$ in Figure 3 . The $C D$ spectra of the human-based analogs, unmodified (U5) and modified

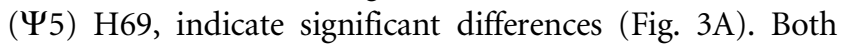
spectra are indicative of A-form RNA structures; however, differences in peak maxima, peak minima, and crossover points are observed, as well as differences in peak shapes. The U5 RNA spectrum has a peak maximum at $264 \mathrm{~nm}$, a peak minimum at $238 \mathrm{~nm}$, and a crossover point at $248 \mathrm{~nm}$. The U5 RNA spectrum also has a broad shoulder around 280 $\mathrm{nm}$. In contrast, the $\Psi 5 \mathrm{RNA}$ spectrum has a peak maximum at $256 \mathrm{~nm}$, peak minimum at $232 \mathrm{~nm}$, and crossover point at $238 \mathrm{~nm}$. The $\Psi 5$ RNA spectrum also has a peak centered near $285 \mathrm{~nm}$ that is not observed in the U5 RNA spectrum. Similar results were observed with E. coli $\mathrm{H} 69$ analogs (Meroueh et al. 2000). The observed differences in the spectral features may be explained by the difference in stacking environments for uridines versus pseudouridines, due to their different arrangements of atoms and glycosidic linkages. In addition, the transition dipoles are altered for $\Psi$ compared to U, leading to CD phase changes (Scott and Zamecnik 1969; Schweizer et
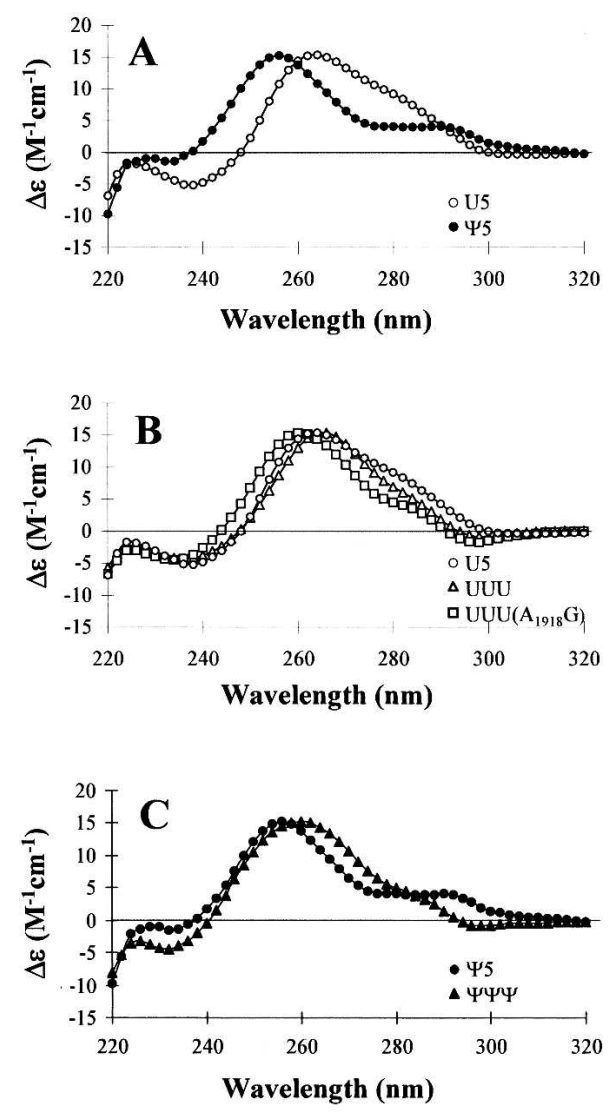

FIGURE 3. CD spectra of unmodified U5 (O) and modified $\Psi 5(\bullet)$ H. sapiens H69 RNAs $(A)$, U5 RNA overlaid with unmodified UUU E. coli RNA $(\triangle)$ and UUU $\left(\mathrm{A}_{1918} \mathrm{G}\right)$ RNA $(\square)(B)$, and $\Psi 5$ RNA and modified $\Psi \Psi \Psi$ E. coli RNA $(\mathbf{\Delta})(C)$ are shown. Each spectrum is an average of four scans, and the RNA concentrations were $2.6 \mu \mathrm{M}$. 
al. 1971; Davis 1995). A comparison of the spectra in Figure 3B also reveals differences between the E. coli and $H$. sapiens RNAs, which is not surprising since they have different stem sequences. The unmodified H. sapiens $\mathrm{H} 69$ (U5) and E. coli H69 (UUU) have similar peak maxima, peak minima, and crossover points. The only difference is that the shoulder around $280 \mathrm{~nm}$ for U5 is slightly shifted to $285 \mathrm{~nm}$ for UUU. The spectrum of the mutant $\operatorname{UUU}\left(\mathrm{A}_{1918} \mathrm{G}\right)$, which has a $H$. sapiens loop sequence and an E. coli stem sequence, is also shown in Figure 3B. This spectrum is unique and differs from both U5 and UUU spectra. The peak maximum, peak minimum, and crossover points are shifted to lower wavelengths (260 nm, $234 \mathrm{~nm}$, and $244 \mathrm{~nm}$, respectively) and the shoulder in the $280-285 \mathrm{~nm}$ region is more pronounced for UUU $\left(\mathrm{A}_{1918} \mathrm{G}\right)$. The CD spectra (Fig. 3C) of the modified RNA analogs ( $\Psi 5$ and $\Psi \Psi \Psi)$ are also different. The extra peak in the $\Psi 5$ spectrum at $285 \mathrm{~nm}$ is not due to the three pseudouridines found in both $H$. sapiens and E. coli $\left(\Psi_{3727}, \Psi_{3731}\right.$, and $\left.\Psi_{3733}\right)$, but rather must come from contributions of one or both of the additional pseudouridines in the stem region $\left(\Psi_{3737}\right.$ and $\left.\Psi_{3739}\right)$ of the H. sapiens RNA. The positive band at 285 $\mathrm{nm}$ also appears in the CD spectra of a duplex RNA representing the stem region of $\Psi 5$ and a single-stranded RNA representing residues $G_{3722}$ through $A_{3728}\left(5^{\prime}\right.$ GGGAGYA-3') (data not shown); however, this band is not apparent in the CD spectrum of a single-stranded RNA representing residues $\mathrm{A}_{3735}$ though $\mathrm{C}_{3740}\left(5^{\prime}\right.$ AC $\left.\Psi C \Psi C-3^{\prime}\right)$. In addition, the peak at $285 \mathrm{~nm}$ is diminished when the $\Psi 5$ or duplex RNA spectra are obtained at $85^{\circ} \mathrm{C}$. These results suggest that the $\mathrm{CD}$ spectral differences between $\Psi 5$ and U5 are due to sequence ( $\Psi$ versus $U$ ) and first-neighbor differences rather than any conformational differences caused by the modified nucleotides.

Circular dichroism spectroscopy is typically more useful for examining changes in RNA structures upon ligand binding or changes in solution conditions. This method was used to examine the overall structures of the U5 and $\Psi 5$ RNAs in the presence of magnesium. Magnesium chloride was added to the RNA samples at total concentrations of 1,3 , and $5 \mathrm{mM}$. The CD spectra of the two human H69 RNAs did not show any significant differences, such as overall shape, crossover points, and peak intensities, upon addition of divalent metal ions (data not shown). For both RNAs, only a slight shift in the peak maxima and crossover points to longer wavelengths $(1-2 \mathrm{~nm})$ was observed with a slight increase in peak intensities at the maxima ( $\sim 0.5$ ellipticity units) upon addition of $5 \mathrm{mM}$ magnesium. Thus, these data indicate that $\mathrm{MgCl}_{2}$ does not significantly affect the structures of U5 and $\Psi 5$.

NMR spectroscopy was employed to determine the hydrogen-bonding patterns for the human H69 RNAs, U5 and $\Psi 5$. The imino proton regions of the $1 \mathrm{D}{ }^{1} \mathrm{H}$ NMR spectra of U5 and $\Psi 5$ are shown in Figure 4. The assignments of the peaks in Figure 4 were made using 1D nuclear Overhauser effect (NOE) difference spectroscopy (data not shown). The U5 spectrum (Fig. 4A, upper panel) shows five sharp imino proton resonances and a sixth broad peak between 10 and $14 \mathrm{ppm}$. In contrast, the $\Psi 5$ spectrum

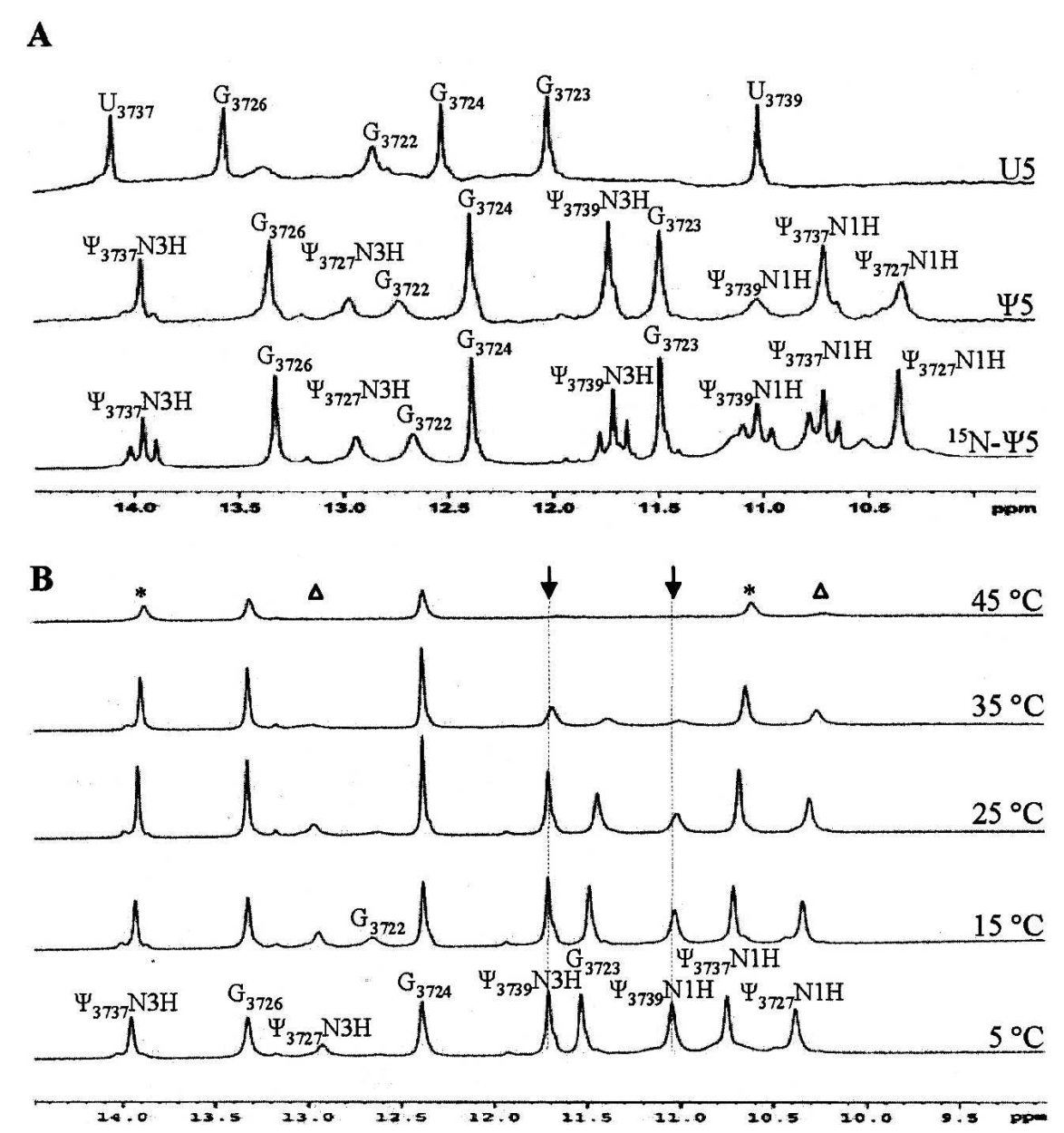

FIGURE 4. The $1 \mathrm{D}$ imino proton (uridine $\mathrm{H} 3$, guanine $\mathrm{H} 1$, and pseudouridine $\mathrm{N} 1 \mathrm{H}$ and $\mathrm{N} 3 \mathrm{H})$ NMR spectra of $H$. sapiens $\mathrm{H} 69$ RNAs, U5, $\Psi 5$, and ${ }^{15} \mathrm{~N}-\Psi 5$. The spectra in $(A)$ were obtained at $15^{\circ} \mathrm{C}$. The spectra in $(B)$ were obtained at $5^{\circ} \mathrm{C}, 15^{\circ} \mathrm{C}, 25^{\circ} \mathrm{C}, 35^{\circ} \mathrm{C}$, and $45^{\circ} \mathrm{C}$. The buffer employed was $30 \mathrm{mM} \mathrm{NaCl}, 10 \mathrm{mM}$ sodium phosphate, and $0.5 \mathrm{mM} \mathrm{Na}_{2}$ EDTA in $90 \%$ $\mathrm{H}_{2} \mathrm{O}$ and $10 \% \mathrm{D}_{2} \mathrm{O}, \mathrm{pH}$ 6.5. Nucleotides are assigned based on 1D NOE spectroscopy (data not shown). In $B$, the symbols are used to indicate resonances derived from the same nucleotide (asterisks for $\Psi_{3737}$, triangles for $\Psi_{3727}$, and arrows for $\Psi_{3739}$ ). 
(Fig. 4A, middle panel) shows 10 imino proton resonances in this region. The assignments are consistent with the formation of five base pairs for the unmodified RNA (U5) (three G-C pairs, one A-U pair, and a G.U mismatch), and six base pairs for the modified RNA ( $\Psi 5)$ (three G-C pairs, two A- $\Psi$ pairs, and a G. $\Psi$ mismatch). The closing G-C base pair $\left(\mathrm{G}_{3722}-\mathrm{C}_{3740}\right)$ is observed for both of the $H$. sapiens H69 RNAs. A loop-closing base pair of the unmodified RNA (U5), $U_{3727}-A_{3735}$, is not observed. In contrast, the $\Psi_{3727}-A_{3735}$ pair is observed in the modified RNA ( $\Psi 5$ ), consistent with earlier studies on the E. coli H69 variants (Meroueh et al. 2000). The fact that the $\mathrm{U}_{3727}-\mathrm{A}_{3735}$ (loopclosing) base pair is not observed suggests that these residues undergo rapid exchange with solvent due to possible conformational differences between $\mathrm{U} 5$ and $\Psi 5$.

In the $\Psi 5{ }^{1} \mathrm{H}$ NMR spectrum (Fig. 4A, middle panel), the resonance at $14.0 \mathrm{ppm}$ is assigned as the $\Psi_{3737} \mathrm{~N} 3$ proton because of a strong NOE to the resonance assigned as $\mathrm{G}_{3726}$ at $13.3 \mathrm{ppm}$ and $\mathrm{A}_{3725} \mathrm{H} 2$ at $7.6 \mathrm{ppm}$. The resonance assignment of the $\Psi_{3737} \mathrm{~N} 3$ proton is further confirmed by employing an ${ }^{15} \mathrm{~N}$-labeled sample of $\Psi 5\left({ }^{15} \mathrm{~N}-\Psi 5\right)$. The ${ }^{15} \mathrm{~N}-\Psi 5$ RNA contains ${ }^{15} \mathrm{~N}$ at positions $\mathrm{N} 1$ and $\mathrm{N} 3$ of the stem pseudouridines, $\Psi_{3737}$ and $\Psi_{3739}$ (Fig. 1). The level of ${ }^{15} \mathrm{~N}$ enrichment is 50\%; therefore, for each ${ }^{15} \mathrm{~N}$ (N1 and $\mathrm{N} 3$ of $\Psi$ ), a combination of a doublet $(\mathrm{J} \approx 85-95 \mathrm{~Hz})$ and singlet peaks is observed. For $\Psi_{3737} \mathrm{~N} 3 \mathrm{H}$, a doublet and singlet centered at $14.0 \mathrm{ppm}$ are observed (Fig. 4A, lower panel, ${ }^{15} \mathrm{~N}-\Psi 5$ ). The identity of $\Psi_{3727} \mathrm{~N} 3 \mathrm{H}$ is confirmed by an NOE to $\mathrm{A}_{3735} \mathrm{H} 2$. The intensity of the $\Psi_{3727} \mathrm{~N} 3 \mathrm{H}$ peak is less than that of the peaks for $\Psi_{3737} \mathrm{~N} 3 \mathrm{H}$ and $\Psi_{3739} \mathrm{~N} 3 \mathrm{H}$, likely due to its location at the end of the helix and greater exposure to solvent.

There are significant differences in the chemical shifts between the U5 and $\Psi 5$ RNAs which were not previously observed with the E. coli modified and unmodified RNAs (Meroueh et al. 2000). For example, $\mathrm{G}_{3723}$ makes a mismatch pair with $\Psi_{3739}$ in $\Psi 5$, and its imino proton peak is shifted upfield by $\sim 0.5$ ppm relative to $\mathrm{G}_{3723}$ in the unmodified U5 RNA (Fig. 4A). Similarly, the chemical shifts for the $U_{3739}$ and $\Psi_{3739} \mathrm{~N} 3$ protons differ by $\sim 0.7 \mathrm{ppm}\left(\Psi_{3739} \mathrm{~N} 3 \mathrm{H}\right.$ is downfield) in the U5 and $\Psi 5$ spectra, respectively. As with the previously mentioned CD spectral changes, the chemical shift changes are likely a result of sequence differences ( $\Psi$ versus $U$ ) and are not necessarily a result of conformational differences between the modified and unmodified RNAs.

The three stem $\Psi$ N1 imino protons $\left(\Psi_{3739}, \Psi_{3737}\right.$, and $\Psi_{3727} \mathrm{~N} 1 \mathrm{H}$ ) are protected from chemical exchange with solvent and are therefore observed in the ${ }^{1} \mathrm{H}$ NMR spectrum of $\Psi 5$ (Fig. 4A, middle panel). These protons exchange at increased temperatures (Fig. $4 \mathrm{~B})$, and in two cases $\left(\Psi_{3739} \mathrm{~N} 1 \mathrm{H}\right.$ and $\Psi_{3727} \mathrm{~N} 1 \mathrm{H}$ ) can no longer be observed at $45^{\circ} \mathrm{C}$, except for a slight broadened peak for $\Psi_{3727} \mathrm{~N} 1 \mathrm{H}$. For the two A- $\Psi$ pairs, the loss of the $\Psi \mathrm{N} 1$ and $\Psi \mathrm{N} 3$ proton resonance intensities ( $\Psi_{3727}$ and $\Psi_{3737}$ ) does not occur simultaneously (at the same temperature), in contrast to previous studies (Hall and McLaughlin 1991). Similarly, in the case of the G- $\Psi$ pair, the
$\Psi_{3739} \mathrm{~N} 3$ proton resonance is much more intense than the $\Psi_{3739} \mathrm{~N} 1 \mathrm{H}$ resonance at elevated temperature.

The assignments of the $\Psi \mathrm{N} 1 \mathrm{H}$ resonances are based on the fact that they exhibit strong NOEs to upfield peaks between 7.0 and $7.4 \mathrm{ppm}$ assigned as $\Psi \mathrm{H} 6$ (Hall and McLaughlin 1992; Meroueh et al. 2000; Newby and Greenbaum 2001). For example, the identity of $\Psi_{3727} \mathrm{~N} 1 \mathrm{H}$ is verified by an NOE to $\Psi_{3727} \mathrm{H} 6$. Cross-peaks are also observed using two-dimensional (2D) nuclear Overhauser effect spectroscopy (NOESY) (data not shown) between the $\Psi \mathrm{N} 1$ proton and $\Psi \mathrm{H} 6$ for each stem pseudouridine, consistent with previous NMR reports on pseudouridine-containing RNAs (Meroueh et al. 2000). Both $\Psi_{3739} \mathrm{~N} 1 \mathrm{H}$ and $\Psi_{3737} \mathrm{~N} 1 \mathrm{H}$ can also be clearly assigned in the ${ }^{15} \mathrm{~N}-\Psi 5$ spectrum, because they appear as a combination of doublet and singlet peaks centered around 11.0 and $10.7 \mathrm{ppm}$, respectively (Fig. 4A, lower panel). The $\Psi_{3739} \mathrm{~N} 1$ proton can be distinguished from $\Psi_{3737} \mathrm{~N} 1 \mathrm{H}$ because it has strong NOEs to the resonances assigned as $\mathrm{G}_{3723}$ and $\mathrm{G}_{3724}$. Similarly, $\Psi_{3737} \mathrm{~N} 1 \mathrm{H}$ has NOEs to the neighboring $\mathrm{G}_{3726}$ and $\mathrm{G}_{3724}$ (data not shown). The $\Psi_{3727} \mathrm{~N} 1$ proton, which does not contain ${ }^{15} \mathrm{~N}$, appears upfield as a singlet at $10.3 \mathrm{ppm}$.

NOEs observed at $7.6 \mathrm{ppm}$ for $\mathrm{U}_{3737} \mathrm{~N} 3 \mathrm{H}$ or $\Psi_{3737} \mathrm{~N} 3 \mathrm{H}$ to $\mathrm{A}_{3725} \mathrm{H} 2$ in the $\mathrm{U} 5$ and $\Psi 5$ samples, respectively, are typical for duplex RNA structures. Similarly, a strong NOE is observed between $\Psi_{3727} \mathrm{~N} 3 \mathrm{H}$ and $\mathrm{A}_{3735} \mathrm{H} 2$ at 7.4 ppm in the $\Psi 5 \mathrm{RNA}$, whereas no peak is observed for the corresponding $\mathrm{U}_{3727} \mathrm{~N} 3 \mathrm{H}$ in $\mathrm{U} 5$. These results indicate that the modified and unmodified human H69 RNAs are both forming standard duplex structures in their stem regions, with no evidence of unusual secondary structures. Overall, NMR studies do not reveal any unusual features of the $\Psi 5$ structure in comparison to U5.

The CD and NMR results presented here suggest that there are only subtle differences between the structures of the modified and unmodified H69 RNAs. In addition, failure to observe imino proton resonances from the RNA loop residues suggests that they are not protected from exchange by a specific RNA conformation. In order to further assess any possible differences between the $\Psi 5$ and U5 RNAs, chemical probing studies were carried out (Peattie and Gilbert 1980). The patterns of diethylpyrocarbonate (DEPC) modification are nearly identical for both RNAs at $37^{\circ} \mathrm{C}$ and $90^{\circ} \mathrm{C}$, suggesting that the loop structures are similar (data not shown).

\section{The effects of modification on stability of the helix 69 RNA analogs}

The melting curves of the H69 RNA analogs were obtained to compare the effects of modification on hairpin stability. For the three RNAs, U5, $\Psi 5$, and UUU(A $\left.A_{1918} \mathrm{G}\right)$, absorbance versus temperature profiles were obtained at $\mathrm{pH} 7.0$ in low salt conditions $\left(35 \mathrm{mM} \mathrm{Na}{ }^{+}\right)$and compared to 
previously studied E. coli RNAs, UUU and $\Psi \Psi \Psi$ (Meroueh et al. 2000). The curves were analyzed in terms of melting temperature $\left(T_{m}\right), \Delta H^{\circ}, \Delta S^{\circ}$, and $\Delta G^{\circ}{ }_{37}$. Representative normalized absorbance plots at single RNA concentrations are shown in Figure 5. All melting curves (except that of UUU) follow a two-state model with unfolded and folded conformations of the $\mathrm{H} 69$ analogs. The helix to random coil transitions occurred between $40^{\circ} \mathrm{C}$ and $80^{\circ} \mathrm{C}$ and were independent of RNA concentration in the range of 5-100 $\mu \mathrm{M}$, suggesting unimolecular unfolding of the hairpin structures. The curve for UUU indicates that the hairpin melts in approximately two stages. The lower temperature transition $\left(<40^{\circ} \mathrm{C}\right)$ likely corresponds to loop destacking because it is concentration-independent. ESI and MALDITOF mass spectrometry data and nondenaturing polyacrylamide gel analysis do not reveal any evidence for duplex formation for any of the RNAs (data not shown). The slightly greater hypochromicity observed with U5 com-
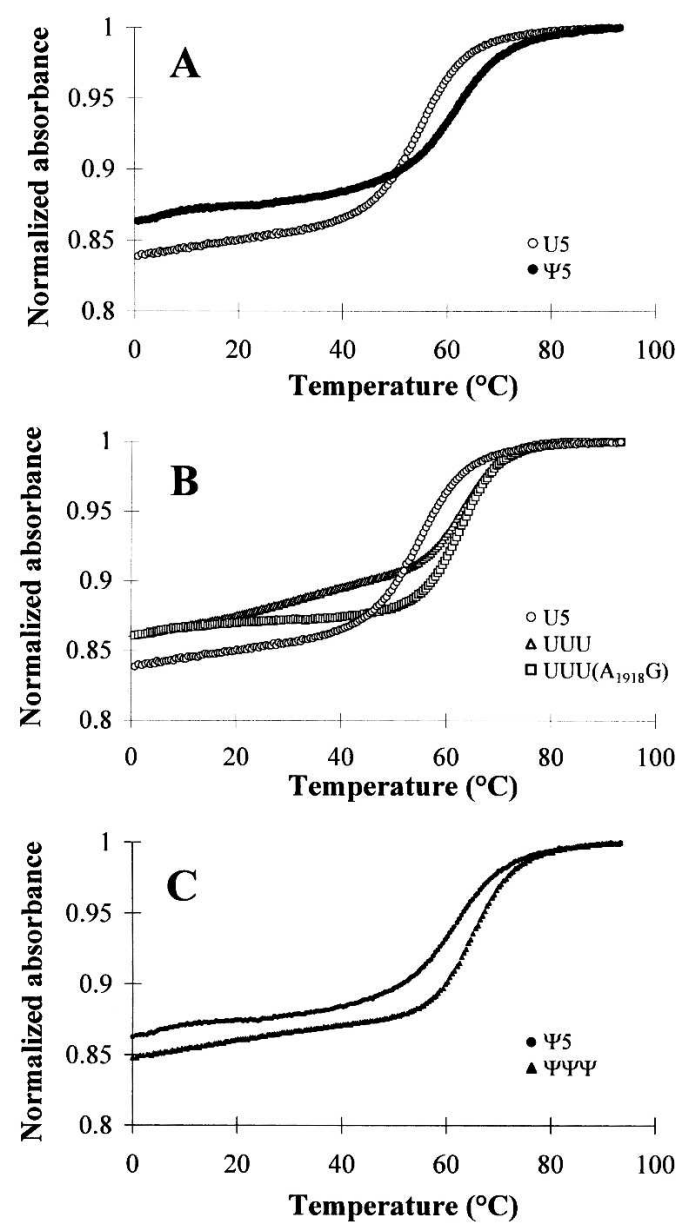

FIGURE 5. The melting curves of unmodified U5 $(O)$ and modified

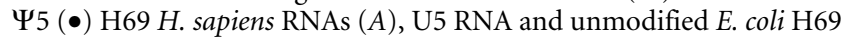
RNA $(\triangle)$ and the UUU $\left(A_{1918} G\right)$ RNA $(\square)(B)$, and $\Psi 5$ overlaid with modified $\Psi \Psi \Psi$ E. coli RNA $(\boldsymbol{\Delta})(C)$. All melting curves are normalized at $95^{\circ} \mathrm{C}$. Buffer: $15 \mathrm{mM} \mathrm{NaCl}, 20 \mathrm{mM}$ sodium cacodylate, $0.5 \mathrm{mM}$ $\mathrm{Na}_{2}$ EDTA, pH 7.0. pared to $\Psi 5$ might suggest that the loop is more stacked, but such small differences are difficult to assess within the experimental error of the melting data.

The most significant difference between the U5 and $\Psi 5$ RNAs is found by comparing their thermodynamic stabilities. The thermodynamic parameters for all five RNAs are listed in Table 2. The $\Delta G^{\circ}{ }_{37}$ values of the unmodified and modified H. sapiens RNAs are -2.7 (U5) and -3.8 ( $\Psi 5)$ $\mathrm{kcal} / \mathrm{mol}$, respectively. Thus, they are $1-2 \mathrm{kcal} / \mathrm{mole}$ less stable than the E. coli RNAs $\left(\Delta G^{\circ}{ }_{37}\right.$ values are $-4.8 \mathrm{kcal} /$ mole for UUU and $-5.0 \mathrm{kcal} / \mathrm{mole}$ for $\Psi \Psi \Psi)$. The difference in stability between the $E$. coli and $H$. sapiens RNAs is in part due to the stem region sequences of the hairpins. The H. sapiens $\mathrm{H} 69$ has an $\mathrm{A}_{3725}-\mathrm{U}_{3737} / \Psi_{3737}$ base pair in place of the E. coli $\mathrm{C}_{1909}-\mathrm{G}_{1921}$ pair. Previous studies demonstrated that pseudouridines in the closing base-pair position stabilize hairpins (Hall and McLaughlin 1991; Durant and Davis 1999; Yarian et al. 1999; Meroueh et al. 2000). In contrast, pseudouridines in loop positions 1915 and 1917 of the E. coli sequence slightly destabilize the hairpin (Meroueh et al. 2000). Thus, the overall differences in $\Delta G^{\circ}{ }_{37}$ values are negligible between unmodified (UUU) and modified $(\Psi \Psi \Psi)$ E. coli-based RNAs $(0.2 \mathrm{kcal} / \mathrm{mol})$, whereas a much larger difference in $\Delta G^{\circ}{ }_{37}$ values of 1.1 $\mathrm{kcal} /$ mole is observed between $H$. sapiens unmodified (U5) and modified ( $\Psi 5$ ) RNAs. The major sequence differences between $E$. coli and H. sapiens H69 RNAs are the seventh base of the loop ( $3^{\prime}$ side, positions 1918 and 3734, respectively) and two additional pseudouridines (positions 3737 and 3739) for $H$. sapiens. The $\operatorname{UUU}\left(\mathrm{A}_{1918} \mathrm{G}\right) \mathrm{H} 69$ variant has a $H$. sapiens loop and $E$. coli stem sequence. The $\Delta G^{\circ}{ }_{37}$ values of UUU and $\mathrm{UUU}\left(\mathrm{A}_{1918} \mathrm{G}\right)$ are similar $(-4.8$ versus $-4.7 \mathrm{kcal} / \mathrm{mol}$ ); therefore, the difference in $\Delta G^{\circ}{ }_{37}$ between U5 and UUU is more likely due to variations in the stem sequences rather than loop sequences. The two additional pseudouridines also contribute $\sim 1.2 \mathrm{kcal} / \mathrm{mole}$ to the stability of the H. sapiens H69. Similarly, previous studies showed that incorporation of a single pseudouridine in the eukaryotic U2 snRNA can stabilize the duplex by -0.7 $\mathrm{kcal} / \mathrm{mole}\left(\Delta G^{\circ}{ }_{37}\right)$ (Newby and Greenbaum 2001).

In the present study, it was also demonstrated that $\mathrm{Mg}^{2+}$ has a stabilizing effect on both E. coli- and H. sapiens-based H69 analogs. Such a result is not surprising given that the magnesium ions can be counter ions for the negatively charged RNA phosphate backbone. The $\Delta \Delta G^{\circ}{ }_{37}$ value for both unmodified (UUU) and modified $(\Psi \Psi \Psi)$ E. coli RNAs in the absence and presence of $1.0 \mathrm{mM} \mathrm{Mg}{ }^{2+}$ is $-1.6 \mathrm{kcal} / \mathrm{mole}$ (Table 2). In contrast, the $\Delta \Delta G^{\circ}{ }_{37}$ values of unmodified (U5) and modified ( $\Psi 5) H$. sapiens RNA $(-1.2$ and $-1.3 \mathrm{kcal} / \mathrm{mol}$, respectively) are lower than the $E$. coli values. The $\Delta \Delta G^{\circ}{ }_{37}$ value of UUU $\left(\mathrm{A}_{1918} \mathrm{G}\right)$ in the presence and absence of $1.0 \mathrm{mM} \mathrm{Mg}{ }^{2+}$ is the same as that of the E. coli sequences $(-1.6 \mathrm{kcal} / \mathrm{mol})$; therefore, the trend of the $\Delta \Delta G^{\circ}{ }_{37}$ values shows that the UUU $\left(\mathrm{A}_{1918} \mathrm{G}\right)$ variant with the $H$. sapiens loop sequence and E. coli stem sequence 
TABLE 2. Thermodynamics of helix 69 RNAs

\begin{tabular}{|c|c|c|c|c|c|}
\hline RNA & $\begin{array}{c}\Delta G^{\circ}{ }_{37} \\
\text { (kcal /mole) }\end{array}$ & $\begin{array}{c}\Delta \Delta G^{\circ}{ }_{37} \\
\text { (kcal/mole) }\end{array}$ & $\begin{array}{c}\Delta H^{\circ} \\
\text { (kcal/mole) }\end{array}$ & $\Delta S^{\circ}$ (e.u.) & $\mathrm{T}_{\mathrm{m}}\left({ }^{\circ} \mathrm{C}\right)$ \\
\hline \multicolumn{6}{|c|}{ Without $\mathrm{Mg}^{2+\mathrm{a}}$} \\
\hline UUU & $-4.8 \pm 0.1$ & & $-61.1 \pm 0.5$ & $-181.4 \pm 1.6$ & 63.5 \\
\hline $\operatorname{UUU}\left(\mathrm{A}_{1918} \mathrm{G}\right)$ & $-4.7 \pm 0.1$ & & $-60.1 \pm 0.8$ & $-178.5 \pm 2.3$ & 63.5 \\
\hline$\Psi \Psi \Psi$ & $-5.0 \pm 0.1$ & & $-59.2 \pm 0.4$ & $-174.6 \pm 1.2$ & 65.7 \\
\hline U5 & $-2.7 \pm 0.1$ & & $-50.2 \pm 1.5$ & $-153.2 \pm 4.6$ & 54.5 \\
\hline$\Psi 5$ & $-3.8 \pm 0.2$ & & $-49.5 \pm 1.1$ & $-147.2 \pm 3.2$ & 62.9 \\
\hline \multicolumn{6}{|c|}{ With $1.0 \mathrm{mM} \mathrm{Mg}^{2+b}$} \\
\hline UUU & $-6.4 \pm 0.1$ & $-1.6^{\mathrm{c}}$ & $-63.7 \pm 0.5$ & $-184.6 \pm 1.2$ & 71.8 \\
\hline $\operatorname{UUU}\left(\mathrm{A}_{1918} \mathrm{G}\right)$ & $-6.3 \pm 0.1$ & -1.6 & $-63.2 \pm 0.8$ & $-183.4 \pm 2.3$ & 71.6 \\
\hline$\Psi \Psi \Psi$ & $-6.6 \pm 0.1$ & -1.6 & $-61.9 \pm 0.7$ & $-178.6 \pm 2.0$ & 73.7 \\
\hline U5 & $-3.9 \pm 0.1$ & -1.2 & $-53.9 \pm 2.3$ & $-161.2 \pm 6.8$ & 61.0 \\
\hline$\Psi 5$ & $-5.1 \pm 0.1$ & -1.3 & $-54.3 \pm 0.8$ & $-158.3 \pm 2.4$ & 69.5 \\
\hline
\end{tabular}

A recent study to determine the location of the ribosome release factor RRF on the $70 \mathrm{~S}$ ribosome revealed another important role for H69 (Agrawal et al. 2004). Contacts with the highly conserved regions of RRF and the loop region of H69 are attributed to specific pseudouridine residues. Direct contact of RRF with these residues may be important for conformation changes in this region and ultimately subunit dissociation.

The UV melting $\left(T_{m}\right)$ data presented in these studies establish that the three pseudouridine residues in the stem region of H. sapiens $\mathrm{H} 69$ provide stabilization to the RNA. In contrast, substitution at position 1918 with a $G$ residue in eukaryotes in place of an A found in bacteria does not affect the RNA stability. The $\mathrm{UUU}\left(\mathrm{A}_{1918} \mathrm{G}\right)$ has an E. coli stem region and $H$. sapiens loop region, but the $\Delta G^{\circ}{ }_{37}$ value is similar to those of the unmodified or modified E. coli H69 RNAs. Previous

behaves more like the bacterial RNA. The differences in magnesium effects on hairpin stability must therefore arise from differences in the stem sequences, and not from the presence or absence of pseudouridine residues.

\section{DISCUSSION}

It has been noted that the number of nucleotide modifications in rRNA increases with evolution (Ofengand et al. 1995). Helix 69 of $H$. sapiens $28 \mathrm{~S}$ rRNA contains five pseudouridines compared to three in the corresponding hairpin in E. coli $23 \mathrm{~S}$ rRNA. Furthermore, modifications tend to occur in functionally important regions of the ribosome, such as the peptidyl transferase center. Several pseudouridines ( $\Psi_{1911}$ and $\Psi_{1917}$ in E. coli $23 \mathrm{~S}$ rRNA) in H69 are universally conserved, and provide a growth advantage to cells (Ofengand and Bakin 1997; Raychaudhuri et al. 1998). Similarly, the A residue at position 1918 of E. coli $23 S$ rRNA is highly conserved among bacteria. The corresponding position (3734 of $28 \mathrm{~S}$ rRNA) in $H$. sapiens and other eukaryotes is a $>98 \%$ conserved $\mathrm{G}$ residue.

Helix 69 of the large subunit rRNA occurs in the bridge region of the $70 \mathrm{~S}$ and $80 \mathrm{~S}$ ribosomes referred to as B2a. CryoEM and X-ray crystallography studies have shown that the conformation of H69 in the large subunit (unbound, 50S) and complete ribosome (bound, 70S) is different (Harms et al. 2001; Yusupov et al. 2001). Thus, H69 is flexible and has a role extending beyond just a structural support for the intersubunit bridge. This flexibility may allow H69 to participate directly in tRNA translocation. For this reason, H69 has been referred to as a 'molecular crane' (Bashan et al. 2003). studies showed that individually, $\Psi_{1911}, \Psi_{1915}$, and $\Psi_{1917}$ have different effects on the stability of E. coli H69; however, when combined, the three $\Psi$ s have little effect on the overall stability of the hairpin (Meroueh et al. 2000). The $\Delta G^{\circ}{ }_{37}$ value of the unmodified human $\mathrm{H} 69$ is less than that of the E. coli H69 (U5 versus UUU) by $>2 \mathrm{kcal} / \mathrm{mol}$. Therefore, additional pseudouridines may be necessary in order to compensate for sequence changes that destabilize the stem of the human analog (the eukaryotic sequence has an A-U pair in place of a C-G pair found in the bacterial RNA). Fahlman et al. (2004) proposed such a strategy in aminoacyl transfer RNAs binding to the ribosome. They suggest that different patterns of contact between the tRNA and ribosome sites have evolved through changes in tRNA sequence and levels of modification such that binding is uniform.

The addition of divalent metal ions such as $\mathrm{Mg}^{2+}$ leads to stabilization of the modified RNAs, but at slightly different magnitudes (the $\Delta \Delta G^{\circ}{ }_{37}$ values, defined as $\Delta G^{\circ}{ }_{37}$ in the presence of $\mathrm{Mg}^{2+}$ minus $\Delta G^{\circ}{ }_{37}$ in the absence of $\mathrm{Mg}^{2+}$, differ by 0.3 to $0.4 \mathrm{kcal} / \mathrm{mol}$ ) for the $H$. sapiens- and E. coli-derived H69 RNAs. These results indicate that the electrostatic environments of the E. coli and H. sapiens H69 RNAs are slightly different. However, these charge differences are clearly derived from sequence changes, not from modified nucleotides. These conclusions are based on the fact that the same $\Delta \Delta G^{\circ}{ }_{37}$ values are found for unmodified (U) and modified ( $\Psi$ ) RNAs in both E. coli and $H$. sapiens $(-1.6 \mathrm{kcal} /$ mole for $E$. coli and -1.2 to -1.3 for human RNAs; Table 2). The E. coli sequence has a G-C base pair in the stem that is replaced with an $A-\Psi$ pair in the human sequence. Previous structural and computational studies revealed the presence of certain magnesium-guanine interactions (Juneau et al. 2001; Petrov et al. 2002). 
The CD and NMR data both reveal that U5 and $\Psi 5$ form canonical A-form helical structures, and substitution of pseudouridine with uridine has subtle effects on the secondary structure of H69. More specifically, the closing base pair $\Psi$ / $\mathrm{U}_{3727}-\mathrm{A}_{3735}$ is observed in the $\Psi 5 \mathrm{RNA}$, but not in the U5 RNA. Also, the NMR data clearly show evidence of additional hydrogen-bonding interactions involving the $\mathrm{N} 1 \mathrm{H}$ positions of the $\Psi$ stem residues (Fig. 4). The use of ${ }^{15} \mathrm{~N}$-labeled $\Psi$ residues was useful for assigning these resonances in the imino proton NMR spectrum. The presence of these resonances is consistent with the formation of water-mediated hydrogen bonds from pseudouridine to the RNA backbone, as has been observed in other $\Psi$-containing RNAs (Arnez and Steitz 1994; Davis 1995; Newby and Greenbaum 2002).

Another unique feature of the $H$. sapiens $\mathrm{H} 69$ stem is the presence of the G. $\Psi$ mismatch. The related G.U mismatch has been identified and characterized in a number of locations within rRNAs (Gautheret et al. 1995), and can provide specific recognition signals in RNA because of its unique structure (Hou and Schimmel 1988; McClain and Foss 1988). A G.U mismatch is present in the E. coli H69 stem, and a G. $\Psi$ mismatch occurs in the human analog in the identical position. Our NMR data indicate that a G. $\Psi$ mismatch does indeed form in the stem of human H69. The hydrogen-bonding pattern appears to be similar to that of the wobble $G \cdot U$ mismatch involving the $\mathrm{GN} 1 \mathrm{H}$ and $\Psi \mathrm{N} 3 \mathrm{H}$; however, the $3 \mathrm{D}$ structure and base orientation remain to be determined.

The roles of the first and seventh nucleotides of the H69 loop also remain to be determined. Even though $\mathrm{G}_{3734}$ is highly conserved in eukaryotic rRNAs and $\mathrm{A}_{1918}$ is similarly conserved in bacterial rRNAs (Fig. 2; Table 1), this sequence difference does not appear to affect the hairpin structure or stability in a significant manner. This nucleotide may play a role in mediating the interactions with other RNA domains within the ribosome, or in altering the dynamics of the loop in the presence and absence of modified nucleotides. Thus, the ${ }^{15} \mathrm{~N}$-labeled RNAs that we have generated will be quite useful for further studies.

The general structures of the E. coli and H. sapiens H69 RNAs appear to be similar in that they are A-form helices with a loop-closing base pair stabilized by an A- $\Psi$ pair. Thus, flexibility of $\mathrm{H} 69$ is likely to be localized in the loop regions for both eukaryotic and bacterial RNAs. Further investigation into the structural differences and similarities between bacterial and human rRNAs is important for the future development of ribosome-binding drugs that can target the intersubunit domains and act as potential antibiotics. ${ }^{15} \mathrm{~N}$ NMR relaxation studies will also lead to a better understanding of the dynamics of regions such as $\mathrm{H} 69$ in mediating ribosome function.

\section{MATERIALS AND METHODS}

\section{Preparation of RNAs}

The 19-nucleotide (19-nt) RNAs used in this study were obtained from Dharmacon Research. These RNAs were chemically synthe- sized on a $1.0 \mu \mathrm{mol}$ scale and deprotected as described (Meroueh et al. 2000). The sequences of the five RNAs are as follows:

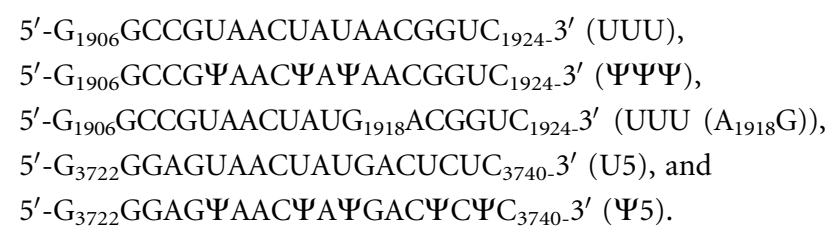

The numbering for UUU, $\Psi \Psi \Psi$, and $\mathrm{UUU}\left(\mathrm{A}_{1918} \mathrm{G}\right)$ is based on fulllength $E$. coli $23 \mathrm{~S}$ rRNA. The numbering for $\mathrm{U} 5$ and $\Psi 5$ is based on fulllength $H$. sapiens $28 \mathrm{~S}$ rRNA. The $\Psi 5$ variant was also synthesized with site-specific ${ }^{15} \mathrm{~N}$ labels at the $\mathrm{N} 1$ and $\mathrm{N} 3$ positions of $\Psi_{3737}$ and $\Psi_{3739}$ $\left(5^{\prime}-\mathrm{G}_{3722} \mathrm{GGAG \Psi AAC \Psi A \Psi GAC}\left({ }^{15} \mathrm{~N}-\Psi\right){ }_{3737} \mathrm{C}\left({ }^{15} \mathrm{~N}-\Psi\right)_{3739} \mathrm{C}_{3740-} 3^{\prime}\right.$; referred to as $\left.{ }^{15} \mathrm{~N}-\Psi 5\right)$. The ${ }^{15} \mathrm{~N}$-containing pseudouridine and its corresponding phosphoramidite were synthesized as described (Grohar and Chow 1999; Meroueh et al. 2000; Hanessian and Machaalani 2003), except that $\left[1,3-{ }^{15} \mathrm{~N}\right]$ uracil (SantaLucia et al. 1995) (from $\left[{ }^{15} \mathrm{~N}\right]$ urea) was employed as a starting material.

The deprotected RNAs were purified on $20 \%$ denaturing polyacrylamide gels (typically $350 \mathrm{~V}$ for $4 \mathrm{~h}$ ). Prior to loading on the gel, the RNA sample contained urea loading buffer [ $7 \mathrm{M}$ urea, $50 \%$ (w/v) glycerol, and $0.1 \%(w / v)$ each of xylene cyanol and bromophenol blue]. The RNA bands were visualized on the gel by UV shadowing with a fluorescent TLC plate. The bands corresponding to the 19-nt RNAs were excised from the gel, and the RNAs were eluted with $0.5 \mathrm{X}$ TBE buffer ( $45 \mathrm{mM}$ Tris, $45 \mathrm{mM}$ boric acid, 0.5 mM EDTA, pH 8.2) at $200 \mathrm{~V}$ for $2.5 \mathrm{~h}$ on an Amicon Centrilutor device. The resulting RNAs were desalted over C18 Sep-Pak columns (Waters), and then dialyzed for 2-3 d against RNase-free, double-deionized water. The ${ }^{15} \mathrm{~N}$-containing RNA was purified by HPLC on an XTerra MS C18 column $(2.5 \mu \mathrm{m}, 10 \times 50 \mathrm{~mm}$, Waters) in which the eluent was 0.1 M TEAA buffer, $\mathrm{pH} 7.0$ with a $7 \%-11 \%$ linear gradient of acetonitrile over $17 \mathrm{~min}$ at a flow rate of $4.0 \mathrm{~mL} / \mathrm{min}$. After HPLC purification, the RNA was desalted by ethanol precipitation and dialysis for 2-3 d against RNase-free, double-deionized water.

RNA concentrations were calculated using Beer's law and single-stranded extinction coefficients $(\varepsilon)$ of $188,860 \mathrm{M}^{-1} \mathrm{~cm}^{-1}$ for UUU and $\Psi \Psi \Psi, 186,500 \mathrm{M}^{-1} \mathrm{~cm}^{-1}$ for $\mathrm{UUU}\left(\mathrm{A}_{1918} \mathrm{G}\right)$, and $191,300 \mathrm{M}^{-1} \mathrm{~cm}^{-1}$ for U5 and $\Psi 5$. The same extinction coefficient was used for uridine and pseudouridine $\left(1.0 \times 10^{4} \mathrm{~cm}^{-1} \mathrm{M}^{-1}\right.$ at $\mathrm{pH}$ 7.0) (Richards 1975). The RNAs were renatured in $10 \mathrm{mM}$ Tris- $\mathrm{HCl}$, pH 7.5 by heating to $90^{\circ} \mathrm{C}$ for $2 \mathrm{~min}$ followed by slowly cooling to room temperature.

\section{Circular dichroism (CD) spectroscopy}

CD spectra were obtained on a Jasco J600 spectropolarimeter $(220-320 \mathrm{~nm})$ at room temperature in $15 \mathrm{mM} \mathrm{NaCl}, 20 \mathrm{mM}$ sodium cacodylate, and $0.5 \mathrm{mM} \mathrm{Na} \mathrm{EDDT}_{2}$ at $\mathrm{pH}$ 7.0. The RNA concentrations were $2.6 \mu \mathrm{M}$ for all $\mathrm{CD}$ experiments. The $\Delta \mathrm{A}$ values were converted to molar ellipticity $(\Delta \varepsilon)$ expressed in moles of RNA molecules (Cantor and Schimmel 1980). The RNA concentrations of each CD sample were determined from the UV absorbance values $(260 \mathrm{~nm})$ at $95^{\circ} \mathrm{C}$. Magnesium chloride (0-5 mM $\mathrm{MgCl}_{2} \cdot 6 \mathrm{H}_{2} \mathrm{O}$ ) was also titrated into the $\mathrm{CD}$ samples. Small volumes $(<5 \mu \mathrm{L})$ were added such that concentration changes were negligible. 


\section{Thermal melting}

The absorbance versus temperature changes were monitored on an Aviv 14DS UV-visible spectrophotometer with a five-cuvette thermoelectric controller. Microcuvettes with two different path lengths $(0.1$ and $0.2 \mathrm{~cm}$; volumes of 60 and $120 \mu \mathrm{L}$, respectively) were employed. The buffer used for this experiment contained 15 $\mathrm{mM} \mathrm{NaCl}, 20 \mathrm{mM}$ sodium cacodylate, and $0.5 \mathrm{mM} \mathrm{Na}_{2}$ EDTA, $\mathrm{pH}$ 7.0. The RNA concentrations of each sample were determined from the UV absorbance values $(260 \mathrm{~nm})$ at $95^{\circ} \mathrm{C}$. The melting curves were obtained from $0^{\circ} \mathrm{C}$ to $90^{\circ} \mathrm{C}$ at $280 \mathrm{~nm}$. The thermodynamic parameters were calculated by using Meltwin 3.5 and assuming a two-state model (McDowell and Turner 1996). The thermal melting experiments just described were also repeated in the presence of magnesium chloride $(1,3$, and $5 \mathrm{mM})$.

\section{NMR spectroscopy}

The NMR spectra for the U5, $\Psi 5$, and ${ }^{15} \mathrm{~N}-\Psi 5$ were obtained on a Bruker AVANCE-AQS $700 \mathrm{MHz}$ spectrometer equipped with a 5-mm triple-resonance cryoprobe. The RNA were dissolved in buffer containing $10 \mathrm{mM} \mathrm{Na}_{2} \mathrm{HPO}_{4}, 0.5 \mathrm{mM} \mathrm{Na} \mathrm{EDTA}_{2}, 30 \mathrm{mM} \mathrm{NaCl}$, and 20 $\mu \mathrm{M}$ TSP in $90 \% \mathrm{H}_{2} \mathrm{O}$ and $10 \% \mathrm{D}_{2} \mathrm{O}, \mathrm{pH}$ 6.5. The final RNA concentrations were $\sim 750 \mu \mathrm{M}$. All NMR spectra were acquired at $15^{\circ} \mathrm{C}$, except for variable temperature experiments that ranged from $5^{\circ} \mathrm{C}$ to $45^{\circ} \mathrm{C} .1 \mathrm{D}$ proton NMR spectra were acquired for all samples using Digital Quadrature Detection for at least 16,000 data points. Samples in 9:1 $\mathrm{H}_{2} \mathrm{O} / \mathrm{D}_{2} \mathrm{O}$ required additional Watergate solvent suppression pulse schemes to be included in the pulse program. Pure $\mathrm{D}_{2} \mathrm{O}$ samples were acquired with added 1 -sec presaturation pulses for HDO signal suppression. 1D NOE difference spectra included a 500-msec presaturation pulse centered on imino peaks of interest. Resulting selective saturation spectra were subtracted from a reference spectrum to determine resonances involved in NOEs. To improve the signal to noise ratio, at least 128 scans were acquired for each experiment. NMR data were processed with zero-filling one time, $1-3 \mathrm{~Hz}$ of line broadening, and solvent signal filters and base-line correction.

\section{ACKNOWLEDGMENTS}

This work is supported by the National Institutes of Health (grant GM54632). We thank Prof. J. SantaLucia for the use of the Aviv spectrometer and many helpful discussions. B. Ksebati, M. Meroueh, and R. Aduri provided technical assistance and useful discussions with the NMR experiments.

Received February 14, 2005; accepted June 6, 2005.

\section{REFERENCES}

Agrawal, R.K., Sharma, M.R., Kiel, M.C., Hirokawa, G., Booth, T.M., Spahn, C.M.T., Grassucci, R.A., Kaji, A., and Frank, J. 2004. Visualization of ribosome-recycling factor on the Escherichia coli 70 S ribosome: Functional implications. Proc. Natl. Acad. Sci. 101: 8900-8905.

Arnez, J.G. and Steitz, T.A. 1994. Crystal structure of unmodified tRNA ${ }^{\text {Gln }}$ complexed with glutaminyl-tRNA synthetase and ATP suggests a possible role for pseudo-uridines in stabilization of RNA structure. Biochemistry 33: 7560-7567.
Badis, G., Fromont-Racine, M., and Jacquier, A. 2003. A snoRNA that guides the two most conserved pseudouridine modifications within rRNA confers a growth advantage in yeast. RNA 9: 771-779.

Ban, N., Nissen, P., Hansen, J., Moore, P.B., and Steitz, T.A. 2000. The complete atomic structure of the large ribosomal subunit at $2.4 \AA$ resolution. Science 289: 905-920.

Bashan, A., Agmon, I., Zarivach, R., Schlünzen, F., Harms, J., Berisio, R., Bartels, H., Franceschi, F., Auerbach, T., Hansen, H.A.S., et al. 2003. Structural basis of the ribosomal machinery for peptide bond formation, translocation, and nascent chain progression. Mol. Cell 11: 91-102.

Bortolin, M.-L. and Kiss, T. 1998. Human U19 intron-encoded snoRNA is processed from a long primary transcript that possesses little potential for protein coding. RNA 4: 445-454.

Cannone, J.J., Subramanian, S., Schnare, M.N., Collett, J.R., D'Souza, L.M., Du, Y., Feng, B., Lin, N., Madabusi, L.V., Muller, K.M., et al. 2002. The comparative RNA web (CRW) site: An online database of comparative sequence and structure information for ribosomal, intron, and other RNAs. BMC Bioinformatics 3: 2-32.

Cantor, C.R. and Schimmel, P.R. 1980. Biophysical chemistry. Part II: Techniques for the study of biological structure and function. W. H. Freeman, San Francisco.

Carter, A.P., Clemons, W.M., Broderson, D.E., Morgan-Warren, R.J., Wimberly, B.T., and Ramakrishnan, V. 2000. Functional insights from the structure of the $30 \mathrm{~S}$ ribosomal subunit and its interactions with antibiotics. Nature 407: 340-348.

Cate, J.H., Yusupov, M.M., Yusupova, G.Zh., Earnest, T.N., and Noller, H.F. 1999. X-ray crystal structure of 70 S ribosome functional complexes. Science 285: 2095-2104.

Charette, M. and Gray, M.W. 2000. Pseudouridine in RNA: What, where, how, and why. IUBMB Life. 49: 341-351.

Chui, H.M.-P., Desaulniers, J.-P., Scaringe, S.A., and Chow, C.S. 2002. Synthesis of helix 69 of Escherichia coli 23S rRNA containing its natural modified nucleosides, $\mathrm{m}^{3} \Psi$ and $\Psi$. J. Org. Chem. 67: 88478854.

Cohn, W.E. 1960. Pseudouridine, a carbon-carbon linked ribonucleoside in ribonucleic acids: Isolation, structure, and chemical characteristics. J. Biol. Chem. 235: 1488-1498.

Davis, D.R. 1995. Stabilization of RNA stacking by pseudouridine. Nucleic Acids Res. 23: 5020-5026.

Durant, P.C. and Davis, D.R. 1999. Stabilization of the anticodon stem-loop of tRNA ${ }^{\mathrm{Lys}, 3}$ by an $\mathrm{A}^{+}-\mathrm{C}$ base-pair and by pseudouridine. J. Mol. Biol. 285: 115-131.

Fahlman, R.P., Dale, T., and Uhlenbeck, O.C. 2004. Uniform binding of aminoacyl transfer RNAs to the ribosomal A and P sites. Mol. Cell 16: 799-805.

Frank, J. and Agrawal, R.K. 2000. A ratchet-like inter-subunit reorganization of the ribosome during translation. Nature 406: 318 322.

Gabashvili, I.S., Agrawal, R.K., Spahn, C.M.T., Grassucci, R.A., Svergun, D.I., Frank, J., and Penczek, P. 2000. Solution structure of the E. coli $70 \mathrm{~S}$ ribosome at $11.5 \AA$ resolution. Cell 100: 537-549.

Gao, H., Sengupta, J., Valle, M., Korostelev, A., Eswar, N., Stagg, S.M., Van Roey, P., Agrawal, R.K., Harvey, S.C., Sali, A., et al. 2003. Study of the structural dynamics of the E. coli $70 S$ ribosome using real-space refinement. Cell 113: 789-801.

Gautheret, D., Konings, D., and Gutell, R.R. 1995. G.U base pairing motifs in ribosomal RNAs. RNA 1: 807-814.

Gregorian Jr., R.S. and Crothers, D.M. 1995. Determinants of RNA hairpin loop-loop complex stability. J. Mol. Biol. 248: 968-984.

Grohar, P.J. and Chow, C.S. 1999. A practical synthesis of the modified RNA nucleoside pseudouridine. Tet. Lett. 40: 2049-2052.

Hall, K.B. and McLaughlin, L.W. 1991. Properties of a U1/mRNA $5^{\prime}$ splice site duplex containing pseudouridine as measured by thermodynamic and NMR methods. Biochemistry 30: 1795-1801.

1992. Properties of pseudouridine N1 imino protons located in the major groove of an A-form RNA duplex. Nucleic Acids Res. 20: $1883-1889$. 
Hanessian, S. and Machaalani, R. 2003. A highly stereocontrolled and efficient synthesis of $\alpha$ - and $\beta$-pseudouridines. Tet. Lett. 44: 8321-8323.

Harms, J., Schluenzen, F., Zarivach, R., Bashan, A., Gat, S., Agmon, I., Bartels, H., Franceschi, F., and Yonath, A. 2001. High resolution structure of the large ribosomal subunit from a mesophilic eubacterium. Cell 107: 679-688.

Hou, Y.-M. and Schimmel, P. 1988. A simple structural feature is a major determinant of the identity of a transfer RNA. Nature 333: 140-145.

Joseph, S., Weiser, B., and Noller, H.F. 1997. Mapping the inside of the ribosome with an RNA helical ruler. Science 278: 1093-1098.

Juneau, K., Podell, E., Harrington, D.J., and Cech, T.R. 2001. Structural basis of the enhanced stability of a mutant ribozyme domain and a detailed view of RNA-solvent interactions. Structure 9: 221-231.

Kowalak, J.A., Bruenger, E., Hashizume, T., Peltier, J.M., Ofengand, J., and McCloskey, J.A. 1996. Structural characterization of $U^{*}-1915$ in domain IV from Escherichia coli $23 \mathrm{~S}$ ribosomal RNA as 3methylpseudouridine. Nucleic Acids Res. 24: 688-693.

Limbach, P.A., Crain, P.F., and McCloskey, J.A. 1994. Summary: The modified nucleosides of RNA. Nucleic Acids Res. 22: 2183-2196.

Maden, B.E.H. and Wakeman, J.A. 1988. Pseudouridine distribution in mammalian $18 \mathrm{~S}$ ribosomal RNA. Biochem. J. 249: 459-464.

Maiväli, Ü. and Remme, J. 2004. Definition of bases in $23 \mathrm{~S}$ rRNA essential for ribosomal subunit association. RNA 10: 600-604.

McClain, W.H. and Foss, K. 1988. Changing the identity of a tRNA by introducing a G-U wobble pair near the $3^{\prime}$ acceptor end. Science 240: 793-796.

McCloskey, J.A. and Crain, P.F. 1998. The RNA modification database-1998. Nucleic Acids Res. 26: 196-197.

McDowell, J.A. and Turner, D.H. 1996. Investigation of the structural basis for thermodynamic stabilities of tandem GU mismatches: Solution structure of (rGAGGUCUC) $)_{2}$ by two-dimensional NMR and simulated annealing. Biochemistry 35: 14077-14089.

Meroueh, M., Grohar, P.J., Qiu, J., SantaLucia Jr., J., Scaringe, S.A., and Chow, C.S. 2000. Unique structural and stabilizing roles for the individual pseudouridine residues in the 1920 Region of Escherichia coli 23S rRNA. Nucleic Acids Res. 28: 2075-2083.

Merryman, C., Moazed, D., Daubresse, G., and Noller, H.F. 1999. Nucleotides in $23 \mathrm{~S}$ rRNA protected by the association of $30 \mathrm{~S}$ and $50 \mathrm{~S}$ ribosomal subunits. J. Mol. Biol. 285: 107-113.

Mitchell, P., Osswald, M., and Brimacombe, R. 1992. Identification of intermolecular RNA cross-links at the subunit interface of the Escherichia coli ribosome. Biochemistry 31: 3004-3011.

Newby, M.I. and Greenbaum, N.L. 2001. A conserved pseudouridine modification in eukaryotic U2 snRNA induces a change in branchsite architecture. RNA 7: 833-845.

- 2002. Investigation of Overhauser effects between pseudouridine and water protons in RNA helices. Proc. Natl. Acad. Sci. 99: 1269712702.

Nissen, P., Hansen, J., Ban, N., Moore, P.B., and Steitz, T.A. 2000. The structural basis of ribosome activity in peptide bond synthesis. Science 289: 920-930.
O'Connor, M. and Dahlberg, A.E. 1995. The involvement of two distinct regions of $23 \mathrm{~S}$ ribosomal RNA in tRNA selection. J. Mol. Biol. 254: 838-847.

Ofengand, J. and Bakin, A. 1997. Mapping to nucleotide resolution of pseudouridine residues in large subunit ribosomal RNAs from representative eukaryotes, prokaryotes, archaebacteria, mitochondria and chloroplasts. J. Mol. Biol. 266: 246-268.

Ofengand, J., Bakin, A., Wrzesinski, J., Nurse, K., and Lane, B.G. 1995. The pseudouridine residues of ribosomal RNA. Biochem. Cell. Biol. 73: 915-924.

Peattie, D.A. and Gilbert, W. 1980. Chemical probes for higher-order structure in RNA. Proc. Natl. Acad. Sci. 77: 4679-4682.

Petrov, A.S., Lamm, G., and Pack, G.R. 2002. Water-mediated magnesium-guanine interactions. J. Phys. Chem. B 106: 3294-3300.

Raychaudhuri, S., Conrad, J., Hall, B.G., and Ofengand, J. 1998. A pseudouridine synthase required for the formation of two universally conserved pseudouridines in ribosomal RNA is essential for normal growth of Escherichia coli. RNA 4: 1407-1417.

Richards, E.G. 1975. Use of tables in calculation of absorption, optical rotary dispersion, and circular dichroism of polyribonucleotides. In Handbook of biochemistry and molecular biology, pp. 596-599. Nucleic acids. CRC Press, Cleveland, OH.

SantaLucia Jr., J., Shen, L.X., Cai, Z., Lewis, H., and Tinoco Jr., I. 1995. Synthesis and NMR of RNA with selective isotopic enrichment in the bases. Nucleic Acids Res. 23: 4913-4921.

Schlünzen, F., Zarivach, R., Harms, J., Bashan, A., Tocilj, A., Albrecht, R., Yonath, A., and Franceschi, F. 2001. Structural basis for the interaction of antibiotics with the peptidyl transferase centre in eubacteria. Nature 413: 814-821.

Schweizer, M.P., Thedford, R., and Slama, J. 1971. Synthesis and conformational properties of diribonucleoside monophosphates containing modified nucleosides as found in transfer RNA. Biochim. Biophys. Acta 232: 217-226.

Scott, J.F. and Zamecnik, P.C. 1969. Some optical properties of diadenosine-5'-phosphate. Proc. Natl. Acad. Sci. 64: 1308-1314.

Spahn, C.M.T., Beckmann, R., Eswar, N., Penczek, P.A., Sali, A., Blobel, G., and Frank, J. 2001. Structure of the 80 S ribosome from Saccharomyces cerevisiae - tRNA-ribosome and subunit-subunit interactions. Cell 107: 373-386.

Wimberly, B.T., Broderson, D.E., Clemons Jr., W.M., Morgan-Warren, R.J., Carter, A.P., Vonrhein, C., Hartsch, T., and Ramakrishnan, V. 2000. Structure of the 30S ribosomal subunit. Nature 407: 327-339.

Wrzesinski, J., Bakin, A., Ofengand, J., and Lane, B.G. 2000. Isolation and properties of Escherichia coli 23S-RNA pseudouridine 1911, 1915, 1917 synthase (RluD). IUBMB Life. 50: 33-37.

Yarian, C.S., Basti, M.M., Cain, R.J., Ansari, G., Guenther, R.H., Sochacka, E., Czerwinska, G., Malkiewicz, A., and Agris, P.F. 1999. Structural and functional roles of the N1- and N3-protons of $\Psi$ at tRNA's position 39. Nucleic Acids Res. 27: 3543-3549.

Yusupov, M.M., Yusupova, G.Z., Baucom, A., Lieberman, K., Earnest, T.N., Cate, J.H.D., and Noller, H.F. 2001. Crystal structure of the ribosome at $5.5 \AA$ A resolution. Science 292: 883-896. 

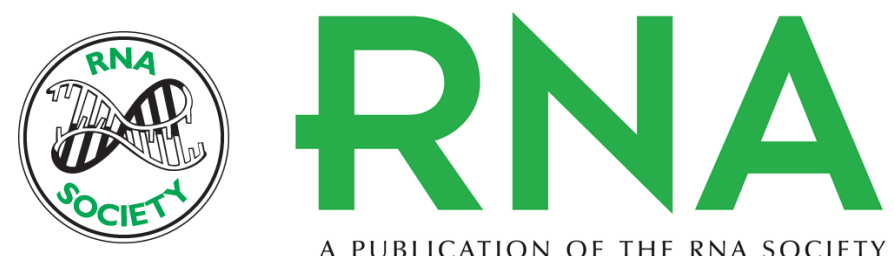

A PUBLICATION OF THE RNA SOCIETY

\section{Effects of nucleotide substitution and modification on the stability and structure of helix 69 from $28 S$ rRNA}

MINAKO SUMITA, JEAN-PAUL DESAULNIERS, YU-CHENG CHANG, et al.

RNA 2005 11: 1420-1429

References This article cites 56 articles, 18 of which can be accessed free at:

http://rnajournal.cshlp.org/content/11/9/1420.full.html\#ref-list-1

\section{License}

Email Alerting Receive free email alerts when new articles cite this article - sign up in the box at the Service top right corner of the article or click here. 